\title{
B14 - IDENTIFICAÇÃO DE NÓS PARA APLICAÇÃO DA FERRAMENTA DE ANÁLISE DE RISCO HAZOP EM SISTEMAS DE BIORREAÇÃO
}

\author{
$\underline{\text { Miguel Angel de la O Herrera }}{ }^{1}$, Elezer Monte Blanco Lemes ${ }^{1}$, Antonio Carlos Augusto \\ da Costa ${ }^{2}$, Aderval Severino Luna ${ }^{2}$. \\ 1. Instituto de Tecnologia em Imunobiológicos Bio-Manguinhos, FIOCRUZ, Rio de \\ Janeiro, Brasil.
}

2. Programa de Pós-Graduação em Engenharia Química, Instituto de Química, Universidade Do Estado do Rio de Janeiro, Rio de Janeiro, Brasil

Objetivo: Este trabalho foi realizado com o intuito de traçar as estratégias e critérios na seleção dos nós (falhas) para aplicação da ferramenta qualitativa de analise de risco HAZOP, considerando como caso de estudo um sistema de biorreação bacteriana para produção de proteínas recombinantes.

Metodologia: Para aplicação da metodologia da análise de risco HAZOP foram utilizados como base os diagramas de tubulação e instrumentação (P\&ID) do equipamento. A identificação dos nós utilizou os critérios de seleção como: ocorrência de mudança de estado ou composição, grandes equipamentos separados com parâmetros de processo distintos, interfaces com outros sistemas que possam interferir com o sistema em estudo, linhas e equipamentos relacionados aos maiores inventários de produtos perigosos, reatores, caldeiras e fornos, trocadores de calor, equipamentos sujeitos à pressurização excessiva, interfaces com sistemas de gases tóxicos. Posteriormente foram agrupados os nós com funções equivalentes ou nos que quando houver falha o resultado desta seria similar, esse critério é fundamentado na premissa que os sistemas de biorreação são altamente complexos e constam de um grande numero de linhas de entrada e saída de materiais, utilidades e produtos, além de contar com diferentes acessórios e equipamentos dentro do mesmo sistema. A seguinte etapa consistiu em determinar o nível de risco dos desvios utilizando uma matriz de risco e foram classificados como: insignificantes, aceitáveis, não desejáveis e não aceitáveis. Por ultimo foram definidas as medidas de mitigação ou redução do nível de risco.

Resultados: Foram identificados cinco nós no sistema de biorreação. O primeiro nó foi definido como distribuição de utilidades constituída pelas linhas de água para injeção, 
água purificada, vapor puro e solução para sanitização e apresentou níveis de risco dos desvios como aceitáveis. O segundo nó das linhas de transferência de soluções necessárias durante o processo de biorreação, manteve o nível de risco dos desvios como aceitáveis. O terceiro nó foi definido como o sistema de trocadores de calor e mostrou níveis de risco aceitáveis e não desejáveis. O quarto nó que foi caracterizado como sistema de filtração de gases de processo e de exaustão apresentou um nível de risco aceitável. O quinto nó identificado como o tanque de processo incluindo as entradas e saídas mostrou um nível de risco de desvios insignificantes e aceitáveis.

Conclusões: $O$ presente trabalho evidenciou que a utilização da ferramenta de análise de risco HAZOP para um sistema novo de biorreação, não substitui o processo de qualificação do equipamento, porém ajuda a promover a aquisição de conhecimentos do equipamento e instalações que serão utilizados posteriormente e assim darão suporte durante a avaliação dos pontos críticos que são o foco de atenção dos procedimentos de Qualificação de Instalação e Qualificação de Operação do sistema exigido pelos órgãos reguladores da área. 